\title{
College English Education Based on New Media Technology
}

\author{
Xiaoqian Sun \\ Zibo Vocational Institute, Zibo, Shandong, 255314, China
}

Keywords: new media technology; college English education

\begin{abstract}
New media technology gradually becomes a very important content in the work and life of modern people. The continuous development of new media drives it to own very unique value in content and expression form, and enters language expression in the form of symbol. In the process of higher education reform, it is required to actively respond to the new idea of modern education, apply new media technology, abandon traditional teaching method and construct the new-type classroom teaching mode. In this paper, the author simply analyzed the influence of new media technology on college English education, expounded the main advantages of new media technology application in college English teaching, analyzed the problems of new media technology application in college English teaching, and proposed the measures to promote college English education under new media technology, exploring English teaching resources, actively adjusting English classroom teaching atmosphere, implementing diversified English micro-course teaching and promoting professional teaching ability of college English teaching.
\end{abstract}

\section{Introduction}

The sustainable development of technicalization and informatization may easily generate important influence on college teaching. English teaching is of great value for improving comprehensive quality of college students. English is the first language in the world, and its application frequency is very high. So, English teaching greatly promotes personal development of contemporary college students. However, under the new trend of continuous development of new media technology, China's college English education has some problems. For example, educational idea change is not timely enough, and learning resources are not rich enough. These have become the important obstacles influencing smooth implementation of college English classroom teaching, and must be solved well. At present, numerous problems exist in college English education, and these are the main factors affecting students' English ability improvement. Under the background of new media teaching, Chinese colleges must change the inherent English education mode, actively apply innovation means and introduce new media technology so as to drive English teaching reform under the new situation, promote all-round and sustainable development of college students and cultivate more high-quality English talents for the country.

\section{Influence of New Media Technology on College English Education}

New media is a new thing with era significance, and mainly covers network media, mobile phone media and digital television. At present, network media and mobile phone media are applied most frequently in college English teaching. Compared with traditional English teaching, college English teaching contents become richer under the influence of new media which can provide more and better resources for college English teaching. The development of college English learning software will provide more convenient platform for college students. It is required to apply new media technology in college English teaching, improve teaching content, effectively innovate for teaching form, continuously improve acceptance of college students, and enhance their learning enthusiasm so as to enhance the effect of college English classroom teaching. 


\section{Main Advantages of New Media Technology Application in College English Education}

Firstly, improve English classroom teaching vitality. The form diversification is an obvious feature of new media technology application. Numerous expression forms of multimedia such as WeChat, QQ or microblog may be used to combine with college English classroom teaching to practically promote driving force of college English teaching. Compared with traditional college English teaching mode, the new teaching method should be fully applied in college English teaching under the condition of new technology application to embody the important function of modern science and technology. Besides, college students can more actively learn English, promote their subjective initiative in English study, better motivate their curiosity and exploration desire for new knowledge and improve their English learning enthusiasm.

Secondly, expand English knowledge learning approaches. In college English teaching, it is required to fully combine the force of new media technology, enrich English teaching knowledge to a larger extent, make English knowledge approaches become diversified, and continuously expand English knowledge reserve sources. College English teachers should apply multimedia software in classroom teaching. College students may also apply multimedia software to enhance and consolidate the knowledge in daily life. Under traditional teaching situation, college students have to passively learn in classroom, and can deeply learn English knowledge through various multimedia teaching tools. Since knowledge learning in English classroom has certain limitation, college students are difficult to understand and grasp knowledge. The emergence and application of multimedia technology greatly relieve this plight. Multimedia technology not just enriches daily life of college students, but also improves their autonomous learning ability and fills up the deficiency of English textbook.

Thirdly, enhance interaction of English classroom teaching. Because college English classroom teaching is integrated with new media technology, the content and expression form of English classroom teaching can be further enriched, and the interaction between teachers and students can improve. Besides, the strong atmosphere of English classroom teaching continues to rise. Under the strong support of new media technology, English teaching in Chinese colleges is no longer dull and boring, but becomes interesting. College English education workers can apply multimedia tools interact with students in extracurricular time. For example, English teachers may register a WeChat account to impart English learning content to students. Students can conduct real-time communication with teachers via WeChat or QQ. Teachers may establish class WeChat group or QQ group to discuss and communicate with students, intensify the interaction with students and drive sustainable development of Chinese higher education.

\section{Problems of New Media Technology Application in College English Education}

Although new media technology has strong influence, the following problems appear when it is applied in college English teaching.

Firstly, college teachers will generate certain gap in teaching concept due to the restriction of personal growth environment and ability to accept education. Based on the new requirements of new media time for college English teaching concept, some teachers' ability to accept new knowledge and new technology is quite limited. The cognition of new media is mainly limited in online game and online shopping. They fail to realize the huge function of new media technology in the teaching process so that they have certain rejection psychology for the teaching means of new media technology. As a result, some teachers fail to effectively combine new media in teaching activities, thus leading to the adverse impact on classroom teaching due to the lack of innovative thinking.

Secondly, although new media technology offers lots of resources for college English teaching, the development degree is not deep enough. Insufficient college English learning resource development is reflected in insufficient resource application. The explored English learning resources focus on CET4, CET6 and postgraduate qualifying examination, and the resources about 
improvement of English oral communication ability and practical application ability are too few. Meanwhile, some English teachers only recommend Chinese English learning websites during choosing learning resources, and lack development awareness for English learning resources in foreign websites.

Thirdly, college network teaching facilities are usually limited to multimedia classroom and corresponding sound equipment, and the configurations for network education facilities are not valued enough. In this way, some college English teachers only display knowledge in the network classroom and fail to guide students to conduct information search and processing.

\section{Measures to Promote College English Education under New Media Technology}

Firstly, fully explore English teaching resources. Nowadays, the continuous development of new media technology drives acceleration of social information communication speed, which is also very prominent in college English classroom teaching. College students are easier to accept fresh things, and will generate innovative thinking. So, fresh things will stimulate their curiosity. If the traditional English education method is still used to let college students accept rigid classroom teaching and boring textbooks and grasp relevant knowledge points only by their memory, they will lose learning enthusiasm. Thus, college English workers must enhance their cognition of important value of new media teaching, fully apply the huge influence of new media to explore useful teaching resources, innovate for teaching contents by new media technology based on current English textbooks, add relevant culture elements in English classroom teaching and continuously improve the overall level of college English education.

Secondly, actively adjust English classroom teaching atmosphere and apply openness nature of new media for interaction and communication. Since college English teaching is easily limited by classroom time and place, it is hard to reach the close communication between teachers and students. After new media is applied, the time-space limit can be broken, and two-way communication between teachers and students is achieved. On the one hand, English teachers may apply campus website, focus on specific teaching content to implement online teaching, combine students' feedbacks to supplement teaching materials, modify and integrate them for students. In this process, college students can apply teacher's guidance to carefully complete English study. Teachers can apply students' feedbacks to improve the teaching link so as to form the virtuous circle of English teaching process. On the other hand, new media tools can overall participate in English teaching management system so as to better promote classroom teaching effect. The author thinks that, all kinds of tools and software related to new media can promote English study of college students. For example, the common communication tool WeChat can be used in English teaching. English teachers can utilize WeChat to keep the close contact with students and then form the fine experience of English teaching. WeChat can promote interpersonal emotion link so as to provide convenience for study and life of modern people. English teachers can link students for interaction through creating class group, and share English teaching experience. This cannot just make the emotion between teachers and students close, but also well mobilize students' learning initiative and teamwork awareness. When WeChat is applied, college students can communicate with English teachers alone and well solve the knowledge points which are not understood and digested. Therefore, WeChat plays a great role in improving English learning results.

Thirdly, implement diversified English micro-course teaching. Micro-course teaching mainly refers to a teaching form based on video teaching, can well help college students improve their learning initiative and continue to motivate students' learning ability. After micro-video teaching is implemented, the effect of viewing anytime and repeated viewing can be realized. College English teachers should implement micro-course study in classroom. English teachers should make simple and short micro-courses according to teaching contents so as to embody the key and difficult points in classroom teaching. Generally speaking, the duration of micro-course should be controlled within $5 \mathrm{~min}$ for the sake of students' study. Students also should be organized for discussion according to 
the content of micro-course teaching so as to continuously promote students' efficient learning ability, and help them seize the focus problems in teaching process, think and solve problems. In the opinion of the author micro-course teaching can ensure students' learning time. The repeated viewing of micro-views can continuously promote classroom teaching effect.

Fourthly, promote professional teaching ability of college English teachers. The introduction of new media teaching means can facilitate English teachers to continuously improve their teaching ability. New media teaching can keep up with the tide of era development, and it is suitable for college English education in the new situation. During implementing English teaching based on new media technology, English teachers should fully apply distinct characteristics of modern network technology, drive the combination of new media and English teaching method, devote themselves to improving personal English learning skills and help college students solve their doubts. It is required to improve the leading role of college English teachers based on new media teaching means, guide college students to learn actively, make adjustments according to students' personalized features and improve English learning quality and ability to the largest extent.

\section{Summary}

In one word, with sustainable development of new media technology, its application in college English education also becomes increasingly common. To better apply new media technology to drive the development of English classroom teaching in Chinese higher education, college English education should adapt to new media environment by all means, and continuously improve new media technology application ability of English education workers so that the group can proficiently apply new media software for communication and exchange, fully mobilize their English study initiative and continuously improve interaction atmosphere of English classroom. It is required to continuously enrich college English teaching resources, combine more new media elements in classroom teaching to enrich English teaching content, and continue to improve college students' English learning level so as to achieve the better development of college English teaching.

\section{References}

[1] Li Xiuhe, Influence of New Media on College Teaching Reform, Literary Education, 2013 (9).

[2] Chen Xuezhen. College English Teaching in New Media Era, Journal of Fujian Medical University (Social Sciences), 2014,(4):57-60.

[3] Fan Xin, Study on Application of New Media in College English Teaching Reform and Innovation, Shipping Vocational Education, 2015 (9).

[4] Wu Chongyang, College English Teaching in New Media Era, Chinese \& Foreign Entrepreneurs, 2016 (32).

[5] Wang Baochuan, Research and Practice of Network New Media in English Teaching, Journal of Shandong Agricultural Administrators' College, 2017 (2). 